Pamiętnik Literacki 2018, 4, s. 251-270

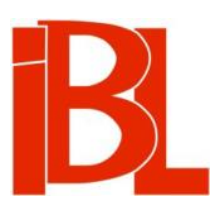

\title{
Dusza rogata. Autobiograficzny wiersz Anny Ludwiki z Mycielskich Radziwilłowej
}

Roman Krzywy 
Pamiętnik Literacki CIX, 2018, z. 4, PL ISSN 0031-0514

DOI: $10.18318 / \mathrm{pl} .2018 .4 .16$

ROMAN KRZYWY Uniwersytet Warszawski

\title{
DUSZA ROGATA AUTOBIOGRAFICZNY WIERSZ ANNY LUDWIKI $Z$ MYCIELSKICH RADZIWIŁLOWEJ
}

\begin{abstract}
Autorka
Życie i twórczość Anny Ludwiki Radziwiłłowej dopiero od niedawna wzbudzają nieco większe zainteresowanie historyków i literaturoznawców, wykraczające poza zestawienia, które wynikają z potrzeb kompendiów bio- czy bibliograficznych ${ }^{1}$. Przyszła żona dwóch Radziwiłłów urodziła się 22 X 1729 w zamożnej rodzinie wielkopolskiej jako córka chorążego nadwornego koronnego Macieja Mycielskiego, który w 1732 roku otrzymał kasztelanię kaliska, w roku 1737 awansował zaś na poznańska, oraz Weroniki z Konarzewskich. Matka była pasierbicą wojewody, a następnie kasztelana krakowskiego Janusza Wiśniowieckiego, ojca nieświeskiej pisarki Franciszki Urszuli, co okaże się nieobojętne nie tylko dla kolei życiowych, ale i dla aspiracji literackich Anny. Natomiast do kariery Mycielskiego oraz wzrostu znaczenia rodu w niemałym stopniu przyczyniła się protekcja księcia Wiśniowieckiego.

O dzieciństwie kasztelanki brak informacji. 16 II 1744 wydano 15-letnią panienkę za starszego o 7 lat krajczyca litewskiego Leona Michała Radziwiłła, po śmierci ojca (1721), Michała Antoniego, pozostającego pod opieką Michała Kazimierza, zwanego Rybeńką, i jego żony, wspomnianej już Franciszki Urszuli. Oni to doprowadzili do małżeństwa zubożałego krajczyca - który po ojcu, prócz znakomitego nazwiska, odziedziczył głównie mocno zadłużone dobra - z urodziwą Wielkopolanką. Niestety, nowożeniec był niezbyt sposobnego zdrowia, na co Anna skarży
\end{abstract}

1 Podstawowy zarys biografii opracowała H. Dymnicka-Wołoszyńska (Radziwiłłowa z Mycielskich Anna Ludwika Karolina Kunegunda. Hasło w: Polski słownik biograficzny. T. 30. Wrocław 1987). Sporo nowych szczegółów na temat zabiegów Radziwiłłowej wokół spraw majątkowych przynosi rozprawa J. Baj er a i A. Maria ni e go Macocha idealna. Aktywność Anny Luizy [!] $z$ Mycielskich Radziwiłłowej $w$ świetle francuskiej korespondencji dyplomatycznej (1764-1765) („Studia Europaea Gnesnensia” 2014). Jeden z utworów Radziwiłłowej ogłosiła z rękopisu przed paru laty D. F e s s e r (Nieznany wiersz Anny z Mycielskich Radziwiłłowej. „Terminus” 2016, z. 3). Także autorka tego ostatniego artykułu konsekwentnie nazywa poetkę „Anną Luiza”. Z kolei B. Po piołek (Kobiecy świat $w$ czasach Augusta II. Studia nad mentalnościa kobiet z kręgów szlacheckich. Kraków 2003, passim) posługuje się imionami „Anna Maria”. W niniejszej pracy przyjęto wersje podaną w albumie rodowym, w którym pisarka figuruje jako „Anna Ludovica Carolina" (zob. M. F. W o b e, Icones familiae ducalis Radivilianae ex originalibus [...] picturis desumptae: inscriptionibus historico-genealogicis [...] illustratae, ab anno [...] 1346 ad annum 1758 deductae. Nesvisii 1758, s. 159). 
się w przypominanej niniejszą edycją jeremiadzie. Zmarł w roku 1751, pozostawiając bardzo młodą wdowę z czwórką dzieci. Znany grafoman Kazimierz Niesiołowski upamiętnił jego przedwczesny zgon sztampowym wierszem, którego szumny tytuł wyraża w istocie brak rzeczywistych dokonań: Epitafijum J[aśnie] O[świeconemu] Ks[iażę]ciu J[ego]m[oś]ci Leonowi Radziwiłłowi, krajczycowi W[ielkiego] Ks[ięstwa] Lit[ewskiego], ordynatowi szydłowieckiemu, generat-majorowi kawaleryi J[ego] K[rólewskiej] M[oś]ci regimentu mirskiego ${ }^{2}$.

Po śmierci męża Anna Radziwiłłowa znalazła patronów w możnej parze książęcej na Nieświeżu oraz w osobie Hieronima Floriana, brata Rybeńki. Formalnej opiece towarzyszyła zapoczątkowana już wcześniej kuratela innego rodzaju, wiążąca się z kształtowaniem umysłowym młodziutkiej krewnej ${ }^{3}$. Jak dobrze wiadomo historykom teatru i literatury, w stolicy ordynacji od 1746 roku działała regularna scena zamkowa (wcześniej sztuki wystawiano w litewskiej siedzibie incydentalnie) ${ }^{4}$, a repertuaru dostarczała jej głównie Franciszka Urszula jako autorka oryginalnych dramatów oraz pierwsza w Polsce adaptatorka komedii Moliera ${ }^{5}$. Była ona ponadto duszą tutejszego życia artystycznego i samorodna poetką, której przygotowanie w zakresie sztuki rymotwórczej ograniczało się do starannej edukacji domowej, odebranej pod okiem preceptorów, specjalnie sprowadzonych przez ojca z zagranicy, oraz do rozlicznych lektur, zwłaszcza francuskich ${ }^{6}$. Ona to przede wszystkim - jak się zdaje - inspirowała nieświeskich dworzan, w tym również i członków rodziny, do uprawiania twórczości literackiej, dbając też o zawartość biblioteki i o rozwój kulturalny podopiecznych ${ }^{7}$. Ów entuzjazm do teatru podzielał mąż księżnej, ale raczej wyłącznie jako widz, gdyż format intelektualny magnata pozostawiał

2 K. Ni es i ołow s ki, Epitafium J[aśnie] O[świeconemu] [...] Leonowi Radziwiłłowi [...]. W: Otia domestica per velocem aquilam et celerem equitem. [Pińsk] 1745, s. 390-391. Jak dowiódł A. S a jkow s ki (Od Sierotki do Rybeńki. W kręgu radziwiłłowskiego mecenatu. Poznań 1965, s. 212), zbiór jest antydatowany - w rzeczywistości ukazał się parę lat później, przed końcem 1752 roku.

3 Zob. B. J u d kow i a k, Franciszka Urszula Radziwiłłowa-w poszukiwaniu własnego głosu. Propozycje interpretacyjne, dokumentacyjne i edytorskie. Poznań 2013, s. 57.

4 Na temat powstania, działalności i repertuaru tutejszego teatru zob. A. S a j k o w s ki, $Z$ dziejów teatru nieświeskiego (1746-1762). „Pamiętnik Teatralny” 1961, z. 3.

$5 \quad$ O pierwowzorach jej sztuk zob. J. Krzyża now s ki, Talia i Melpomena w Nieświeżu. Twórczość U. F. Radziwitłowej. Jw.

$6 \quad$ Niewykluczone, że najbliższy prawdy o wykształceniu magnatki był jej pierwszy biograf, który w nieco zapomnianym omówieniu podał nader dokładne informacje na ten temat: „Spokrewniony z nieszczęśliwym królem Stanisławem Leszczyńskim, [ojciec, tj. Janusz Wiśniowiecki] sprowadził za tegoż poradą najprzedniejszych z zagranicy nauczycielów, którym poruczył wychowanie swojej Urszuli. Z młodości już okazywała nadprzyrodzony smak do rymotwórstwa i wyszczególniała się bystrym pojęciem [...]. Uczyła się języka francuskiego, włoskiego i angielskiego, czytywała najlepsze twory tych narodów, a z latami rozwijał się jej talent. Ojciec przytomny często nauce i czytaniu klasyków sam zwracał jej uwagę na szczytniejsze miejsca w ich dziełach, przez co zaostrzał jej sąd i uczył ją podług prawideł zdrowej krytyki oceniać dzieła zaszczyt przynoszące literaturze; dzieł zaś poślednich zabraniano jej czytać [...]" (S. J a s z o w s k i, O życiu i dziełach Urszuli z ksiażąt Wiśniowieckich księżny Radziwiłłowej, wojewodziny wileńskiej. „Pszczoła Polska” 1820, nr 10, s. 117-118). Zob. też J u d k owi a k, op. cit., s. 19-21. I. C z a mań s k a (Wiśniowieccy. Monografia rodu. Poznań 2007, s. 391) przypuszcza ponadto, że przyszła dramatopisarka mogła kształcić się u lwowskich dominikanek.

$7 \quad$ Na temat erudycji księżnej zob. B. J u d kow i a k, Formacja umysłowa sawantki połowy wieku. (Świat ksiażek $i$ środowisko literackie Franciszki Urszuli Radziwiłłowej). W zb.: Kultura literacka 
wiele do życzenia. Alojzy Sajkowski nazwał go nawet „bęcwałem litewskim”, dając nader wyrazista charakterystykę księcia:

Pan krociowej fortuny o mentalności Chryzostoma Paska (ale nie jego serca, bo mimo iż hetmaństwem się szczycił, zajęczą miał naturę) [...], drapieżny wobec słabszych od siebie, z wykształceniem żenująco ubogim, nabożny niczym baba kruchciana, z całym ekwipunkiem przesądów i zabobonów ${ }^{8}$.

Nic dziwnego, że brak świadectw, by magnat parał się twórczością poetycką. Potrzebę taką wykazywała - i to od pierwszych lat małżeństwa - jego lepsza połowa, komponując w wolnych od zajęc chwilach poetyckie listy, utwory dydaktyczne, religijne, humorystyczne, okolicznościowe czy osobiste - wzbudzające dziś największe zainteresowanie jako wyraz przebijania się głosu kobiecego w poezji, odmiennego od dominujących w XVIII stuleciu androcentrycznych standardów kulturowych $^{9}$. Spuścizna liryczna księżnej z Wiśniowieckich Radziwiłłowej wciąż dostępna jest zreszta jedynie fragmentarycznie, co nie ułatwia całościowego rozpoznania ${ }^{10}$. Aspiracje pani kresowego Parnasu oddziaływały na jej podopiecznych, przynajmniej niektórych, sięgających po pióro, by ułożyć rokokowy erotyk czy wiersz okolicznościowy. Teksty te, łącznie z dorobkiem księżnej, składają się na obraz interesującej, choć efemerycznej wspólnoty komunikacyjnej, stanowiącej kontekst poczynań literackich Franciszki Urszuli ${ }^{11}$. W manuskryptach zachowały się choćby jej wiersze skierowane do Anny Ludwiki i jej męża Leona Michała, a także utwory adresowane przez podopiecznych do niej samej czy również rymowane responsy osobom spoza najbliższego otoczenia księżnej. Wspólnota ta miała, jak łatwo zauważyć, charakter rodzinno-towarzyski.

Jej aktywną uczestniczką była pani krajczycowa, której dorobek znamy wciąż cząstkowo. Wiadomo, że występowała ona też na scenie nieświeskiej. 19 III 1756 (czyli już po śmierci Franciszki Urszuli) zagrała żonę Putyfara w sztuce autorstwa swego brata, Stanisława Mycielskiego, Józef patryjarcha ${ }^{12}$. Można przyjąć, iż w aktorskie rzemiosło wprawiła się jeszcze za życia swej dobrodziejki, która zmarła w 1753 roku. Niecały rok po jej śmierci urodziwa i wciąż młoda Anna Ludwika wyszła za Rybeńkę, zostając panią hetmanową. Niewykluczone, że uprawianie poezji uważała za aktywność właściwą magnackiej pozycji, dziedzicząc to przeko-

połowy XVIII wieku w Polsce. Studia i szkice. Red. T. Kostkiewiczowa. Wrocław 1992, s. $147-156$.

8 Saj k ow s ki, Od Sierotki do Rybeńki, s. 154-155. Zob. też s. 142, 216. Próby zniuansowania tego niepochlebnego wizerunku podjął się K. Zu ba (Michał Kazimierz Radziwiłt 〈1702-1762〉. Portret psychofizyczny. „Medycyna Nowożytna” 2002, z. 1/2, s. 77-82), lecz ostatecznie nie przyniosła ona nazbyt pozytywnych rezultatów.

9 Na temat lirycznej twórczości księżnej zob. B. J u d kow i a k, Słowo inscenizowane. O Franciszce Urszuli Radziwitłowej - poetce. Poznań 1992.

10 Dorobek liryczny pisarki $z$ wyszczególnieniem znanych przekazów rękopiśmiennych oraz edycji rozproszonych po antologiach i innych publikacjach rejestruje aneks w książce Judkowiak Franciszka Urszula Radziwiłłowa - w poszukiwaniu własnego głosu (s. 409-417). Badaczka nie dotarła do wykorzystanego w niniejszym artykule manuskryptu Bibl. Baworowskich, w którym również znajdują się wiersze poetki.

11 Zob. J u d k ow i a k: Stowo inscenizowane, s. 90-91; Formacja umysłowa sawantki połowy wieku, s. 156-161.

12 Zob. Sajkow ski, Od Sierotki do Rybeńki, s. 164-165. 
nanie po poprzedniczce albo też kontynuując zaszczepiony przez nią nawyk poezjowania. Zdaje się to potwierdzać opinia Marcina Matuszewicza, który w swym pamiętniku zanotował pod rokiem 1763 :

Rezydowała ta pani w wielkiej dla każdego gościa ludzkości. Dam swego fraucymeru miała ze dwadzieścia, $z$ którymi bawiła się $\mathrm{w}$ skromnej wesołości. Sama im pieśni różne komponowała, gdyż wiersze polskie dosyć dobrze pisze. Noty im także komponowała, które, różnych głosów dobrawszy, dosyć wdzięcznie śpiewać kazała ${ }^{13}$.

\section{O sobie samej, ale czy do potomności?}

Wiersze $\mathrm{z}$ melancholijej po śmierci śp. męża mego najukochańszego pisane, $w$ których opisane jest całe życie moje ułożyła Radziwiłłowa jako 22-letnia wdowa, matka czworga dzieci, kobieta osierocona przez możnego ojca i przez to zależna od wsparcia rodziny męża. Żałoba, a także przeciagająca się choroba najstarszego syna skłoniły ją do refleksji na temat własnego życia, która wbrew tytułowi nie jest regularną autobiografią, lecz raczej rozpamiętywaniem Bożych dopustów i własnych cierpień, zespolonym z pochwała Stwórcy oraz modlitewnymi suplikacjami. Celem pisarskim nie było zatem uwiecznienie swego istnienia, autopanegiryk skierowany do potomnych, ale akt religijny: rozmowa $z$ Bogiem, złożenie deklaracji uzasadniających korne prośby w intencji zmarłego męża, a także ofiarowanie pieczy Opatrzności zdrowia dzieci. Zamysł taki jasno wynika $z$ kompozycji utworu.

Po obszernej apostrofie, w której autorka, nawiązując do Księgi Rodzaju albo też do sformułowań psalmisty (por. np. Ps 8), chwali Boga za wyróżniający pozycję człowieka akt stwórczy, zobowiązujący ludzi do całkowitego zawierzenia Jego woli, zastrzega, że tylko Zbawicielowi, nie obłudnemu światu, pragnie ofiarować swe stroskane myśli. Tylko On, nie inni ludzie, zna naprawdę jej cierpienia i może być adresatem tych osobistych gorzkich żalów, wyłącznie On zasługuje na szczerość w świecie, w którym rządzi konwenans. Refleksję nad doświadczeniami krótkiego życia kojarzy zatem pisarka $z$ sytuacją intymnej rozmowy z Bogiem, choć niewątpliwie jest to wynik nie tylko potrzeby ducha, lecz również pewnej konwencji.

Dałoby się wskazywać rozmaite inspiracje, które autorka mogła mieć na względzie. Naturalnym modelem dla modlitewnego wyznawania strapień przed Bogiem była, oczywiście, liryka psalmiczna. Lament nad własnym położeniem, prośby o ratunek, deklaracje wierności i zaufania, narzekanie na nieprzyjaciół - to przykładowe motywy, stanowiące część wspólną biblijnych psalmów oraz poematu Radziwiłłowej (por. np. Ps 3, 4, 7, 10, 16-18, 25, 27, 30, 51, 69, 71, 88). Podobna sytuacja komunikacyjna i frazeologia występowały jednak równie często w popularnej literaturze dewocyjnej ze stuleci XVII i XVIII, służącej indywidualnemu nabożeństwu, która w przemożny sposób kształtowała postawy wobec Boga, mogąc stwarzać wzorce modlitewne dla domorosłych poetów ${ }^{14}$. Zacytujmy dla przykładu fragment wierszowanej modlitwy z dziełka opublikowanego przez Macieja Głoskow-

13 M. Matuszewicz, Diariusz życia mego. T. 2: 1758-1764. Oprac., wstęp B. Królikowski. Komentarz Z. Zi elińs ka. Warszawa 1986, s. 267.

14 Aczkolwiek zaznaczyć należy, że komponenty modlitewne i apostrofy do Boga stanowiły także topikę różnych odmian poezji lamentacyjnej. 
skiego po raz pierwszy około roku 1646, lecz wznawianego w czasach staropolskich jeszcze trzykrotnie $(1653,1714,1740)$, co świadczy o dużym zainteresowaniu tego rodzaju piśmiennictwem:

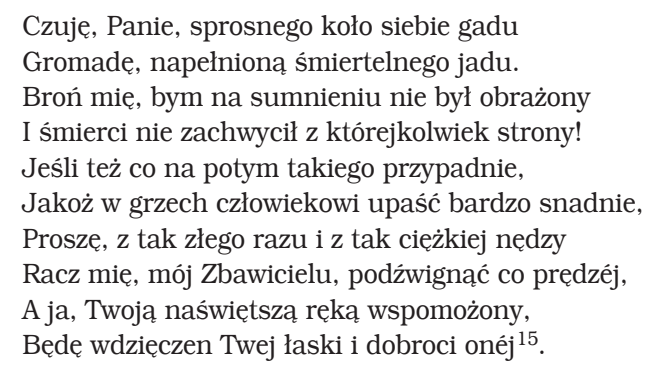

Od dykcji modlitewnych psalmów czy od wzorców dewocyjnych odróżnia wiersz Radziwiłłowej autobiografizm, rozumiany jako potrzeba skojarzenia wydarzeń $z$ własnego życia $z$ refleksją religijną. Liczne apostrofy do Boga podwyższają rejestr stylistyczny, prowadząc do patosu, niepozbawionego liryzmu, lecz bezpretensjonalnej liryczności nie można odmówić także osobistym wynurzeniom.

Snując rozważania nad swymi niedolami, podaje autorka w zasadzie niewiele faktów. Wspomina zamążpójście w młodym wieku, informuje o chorobie męża, którego szczerze pokochała, i o jego zgonie, także o śmierci ojca, następnie enigmatycznie pisze o obmowach, mających naruszać jej dobre imię, o opiekunach, o chorobie syna Mikołaja. Jednak to nie skrupulatne wyliczanie danych biograficznych zajmuje Radziwiłłowa, lecz wyrażenie emocji i religijności. Płaczliwy ton lamentacji złagodzony został przez hiobowe pogodzenie się $\mathrm{z}$ wolą Boga, który doświadczając utrapieniami, dodaje „siły do onych znoszenia” (w. 96). I chociaż Radziwiłłowa świadoma jest swej lichej a grzesznej natury, jako udręczona i osierocona wdowa ośmiela się w zamknięciu wiersza prosić o zbawienie dla zmarłego męża tudzież o ocalenie dzieci. Dominujące w końcowych partiach utworu samouniżenie, połączone $z$ prośbami o miłosierdzie i o wzbudzenie żarliwości religijnej, prowadzi do finalnej supliki, w której - zgodnie z ówczesną pobożnością pasyjna zbolała matka składa w ranach Chrystusa swe potomstwo oraz siebie samą, błagając o zachowanie przy życiu.

Ten sposób wyrażenia własnych doświadczeń daleki jest od kunsztu literackiego, jednak ujmuje bezpośredniością i odmiennością od poezji głównego nurtu. Zachęca to do przypomnienia autobiograficznej lamentacji Anny Ludwiki Radziwiłłowej - kolejnej przedstawicielki staropolskiej twórczości kobiecej, której wiersze wciąż oczekują wydobycia $\mathrm{z}$ manuskryptów ${ }^{16}$.

M. Gło s k o w s ki, Zegarek abo Pamiatka gorzkiej męki i śmierci Zbawiciela naszego Jezusa Pana. B. m., [ok. 1646], s. 51. (W cytacie została zmodernizowana ortografia i interpunkcja.) Wznowienia rejestruje Bibliografia literatury polskiej „Nowy Korbut” (t. 2: Piśmiennictwo staropolskie. Oprac. zespół pod kier. R. Polla ka. Warszawa 1964, s. 198).

16 Na utwór zwrócił uwage, nadmienić należy, nieoceniony A. Sajk ow s ki w książce Staropolska miłość. Z dawnych listów i pamiętników (Poznań 1981, s. 24-26). 


\section{Komentarz edytorski}

Prezentowany w artykule utwór zachował się w dwóch przekazach rękopiśmiennych. Żaden $\mathrm{z}$ nich nie jest autografem:

B - rękopis Lwowskiej Narodowej Naukowej Biblioteki Ukrainy im. W. Stefanyka, zbiory Biblioteki Baworowskich, zespół 4, dział 1, sygn. 835. Jest to sylwa z XVIII wieku, zawierająca w przeważającej mierze utwory poetyckie różnych autorów (prócz publikowanej obecnie autobiografii także wiersze np. Elżbiety Drużbackiej, Franciszki Urszuli Radziwiłłowej, Udalryka Krzysztofa Radziwiłła) ${ }^{17}$, które wpisano staranną dłonią. Inna ręka opatrzyła manuskrypt nagłówkiem Poezje Anny z Mycielskich, księżny Radziwiłłowej, małżonki ks[ię]cia Michała Radziwiłła, hetmana polnego W[ielkiego] Ks[ięs]tw[a] Lit[ewskiego] za czasów panowania Augusta III. Nie wiadomo, czy tytuł ten oznacza, że kolekcja należała do księżnej, czy też bibliograf zasugerował się treścią wierszy autobiograficznych, w których podano jej personalia, i jej właśnie pochopnie przypisał autorstwo wszystkich wierszy. Ta sama osoba zanotowała na oklejce oprawy: Poezje ks[ię]żny Radziwiłłowej Anny, lecz na odwrocie oprawy i karty tytułowej dodała informacje, z których wynika, iż wśród wierszy pomieszczonych w zbiorze rozpoznała także dzieła Franciszki Urszuli Radziwiłłowej. Odesłanie do tomu 2 Dykcjonarza poetów polskich Hieronima Juszyńskiego (Kraków 1820), skąd zaczerpnięto wiadomości na jej temat, świadczy, że adnotacje pochodza już z XIX wieku. Jak ustaliła Dominika Fesser, wpisał je krakowski księgarz i historyk Ambroży Grabowski, od którego kopiariusz w roku 1855 odkupił hrabia Wiktor Baworowski ${ }^{18}$. Wcześniejsze losy manuskryptu nie sa znane. Tekst poematu Anny Ludwiki Radziwiłłowej umieszczony został na kartach 44r-49v. Nie jest on kompletny, urywa się na wersie 332.

$\mathrm{J}$ - rękopis Biblioteki Jagiellońskiej, sygn. 119, t. 1. To kodeks z XVIII wieku, pochodzacy $\mathrm{z}$ archiwum Andrzeja Stanisława Załuskiego. Zawiera miscellanea historyczne i literackie $z$ czasów Augusta II i Augusta III. Pełny tekst poematu wpisano w dwóch kolumnach na kartach 25r-27r.

Analiza błędów występujących w obu przekazach pozwala stwierdzić, że reprezentują one niezależne tradycje tekstu. Żadna $\mathrm{z}$ kopii nie jest na tyle poprawna, by można ją przyjąć za podstawę edycji, stąd też tekst utworu restytuowano, opierając się na obu źródłach, dokumentując wybór lekcji w aparacie krytycznym zamieszczonym w przypisach.

Przygotowując transkrypcję, kierowano się następującymi zasadami:

- w edycji zastosowano obecne reguły przestankowania (w obu rękopisach znaki interpunkcyjne nie były używane);

- skróty rozwinięto, ujmując uzupełnienia w nawiasy kwadratowe;

- pozostałości grafii łacińskiej spolszczono, np. affektu $\rightarrow$ afektu, excypować $\rightarrow$ ekscypować;

17 W sylwie pomieszczono dworskie utwory miłosne, wiersze okolicznościowe, dydaktyczne i religijne. Autorstwo kilku określiła D. Fesser (Nieznany rękopis z Bavorovianum. Perspektywy badań zdigitalizowanych zbiorów z Lwowskiej Narodowej Naukowej Biblioteki Ukrainy im. Wasyla Stefanyka. „Nowa Biblioteka” 2016, nr 3, s. 47-48), jednak większość wymaga badań atrybucyjnych.

Zob. ibidem, s. 46. 
- uporządkowano pisownię małych i dużych liter zgodnie z dzisiejszymi normami;

- zmodernizowano pisownię łączną i rozdzielną, np. nie znośna $\rightarrow$ nieznośna, przedemna $\rightarrow$ przede mna; partykułe -li oddzielono dywizem w słowie czy-li ('czy też);

- występujących w przekazach oboczności o rozmaitym charakterze gramatycznym (np. obszernym || obszyrnym, władzy || władzej, wspominać || spominać, wszystkiego || wszytkiego) nie respektowano, preferując formy obecne;

- w związku z tym, że nosowość samogłosek przez obu kopistów była niestarannie oznaczana, a ponadto w przekazie $J$ widoczna jest tendencja do unasawiania wygłosu (np. daje, mocna, ta, twoję zamiast daje, mocno, to, twoje), należało transkrypcję uzależnić od znaczenia sformułowań (w aparacie uwzględniono tylko miejsca wątpliwe);

- pisownię $o$, u uwspółcześniono, np. ktore $\rightarrow$ które, szczegulnie $\rightarrow$ szczególnie, odstępując od reguły, gdy wymagała tego poprawność rymu, np. proba-choroba;

- zachowano ścieśnioną wymowę a w słowie kożdego;

- pochylenie $e$ (é) oznaczano jedynie w pozycjach rymowych, np. troski-boskiéj, winy - jedynéj; zachowano ścieśnioną wymowę w słowach: myślić (i pochodnych), potym;

- zmodernizowano grafię $i, y, j$, np. twoiey $\rightarrow$ twojej, y bez $\rightarrow i$ bez; rozszerzono $i, y \mathrm{w}$ słowach pochodzenia obcego, gdy występowały w grupach samogłoskowych, np. kompasya $\rightarrow$ kompasyja, melancholii $\rightarrow$ melancholiji;

- dźwięczność i bezdźwięczność spółgłosek uzgodniono z dzisiejszymi regułami, np. cięszko $\rightarrow$ ciężko, wież $\rightarrow$ wiesz, żebydź $\rightarrow \dot{z} e b y c ́ ;$

- obaj kopiści często pomijali znaki diakrytyczne, które w transkrypcji uzupełniono, np. laskawie $\rightarrow$ taskawie, małżenstwie $\rightarrow$ małżeństwie, wyznac $\rightarrow$ wyznać, zalach $\rightarrow$ żalach;

- zachowano przykład archaicznej grupy spółgłoskowej w formie źrzenic, a także uproszczenia spółgłoskowego w słowie czyśca; nie modernizowano dawnej postaci leksemów: najprzód, spólnie;

- w dawne formy fleksyjne nie ingerowano.

ANNA LUDWIKA Z MYCIELSKICH RADZIWIŁŁOWA

\section{WIERSZE Z MELANCHOLIJEJ PO ŚMIERCI ŚP. MĘŻA MEGO NAJUKOCHAŃSZEGO PISANE, W KTÓRYCH OPISANE JEST CA£E ŻYCIE MOJE ${ }^{1}$}

Wszechmocny Rządco nieba, ziemi, morza, Którego dzieła powstająca zorza

$1 \quad$ Rkps B: Krótkie opisanie wierszem życia J[aśnie] O[świeconej] Księżnej J[ej]m[oś]ci Anny z Mycielskich Radziwiłłowej, generałowej-majorowej wojsk W[ielkiego] Ks[ięstwa] L[itewskiego], po śmierci męża swego 1751. 
Jaśnie odkrywa stworzonemu oku Na świata tego obszernym widoku,

Tyś absolutnym Panem jest wszystkiego,

Co tylko widzieć można stworzonego,

Co tchnie na ziemi, na powietrzu żyje

I co w głębokich nurtach woda kryje ${ }^{2}-$

To dla człowieka stworzyłeś, mój Panie,

I co rozkażesz, wszystko wraz się stanie.

Temu żywioły prawie $^{3}$ niezliczone

Pod moc poddałes ${ }^{4}$, jego zostawione

Władzy są wszystkie insze kreatury,

Bo doskonalszej jest nad nie natury ${ }^{5}$.

On sam na Twoje jest wyobrażenie

Uformowany, przez Twej ulepienie

Wszechmocnej ręki i nieśmiertelnego

Ducha Twym tchnieniem inspirowanego ${ }^{6}$.

Ty masz sam nad nim absolutne prawo,

$20 \quad$ Czy-li łaskawie, czy-li sobie żwawo ${ }^{7}$

$Z$ nim chcesz postąpić, od Twojej to woli

Zawisło, w jakiej żyć mu każesz doli.

On zawsze skłaniać do Twego przejrzenia

Swoje powinien chęci i pragnienia ${ }^{8}$,

25 Bo się inaczej stać nigdy nie może,

Tylko jako Ty dysponujesz, Boże.

Choć nam się ciężkie umartwienie zdawa,

Przecie że $z$ Twego ojcowskiego prawa

Włożone na nas ${ }^{9}$, skarżyć się nie godzi,

Bo ta myśl wszystkie umartwienie słodzi.

Niechaj się, kto chce, uskarża i stęka,

Że go wszechmocna Twoja martwi ręka,

Czy-li przez próbę, czy-li przez karanie

Wyznawa się być w opłakanym stanie,

Ja w umartwieniach końca ani miary,

Lubo to wielu ${ }^{10}$ rzecz trudna do wiary,

Nie znając, żalić nie chcę się przed światem,

Bo w żalach ulgi nie zakładam ${ }^{11}$ na tem.

Rkps B: woda żyje.

prawie - rzeczywiście, prawdziwie.

Rkps B: Poddateś pod moc.

5 Początek utworu (w. 1-14), zwłaszcza myśl o podporządkowaniu świata natury człowiekowi jako istocie najwyżej postawionej w hierarchii stworzeń, znajduje paralelę w Psalmie 8.

inspirowanego - tj. ożywionego; w. 9-18 por. Rdz 1, 26-29; 2, 7.

żwawo - kąśliwie, zjadliwie, tu: surowo, ostro.

Rkps J: Swojej powinien chęci, upragnienia.

Wtożone na nas - zasądzone nam.

Rkps B: Lubo to $w$ wielu.

nie zaktadam - nie opieram. 
Wiedząc światowej obłudy igrzyska ${ }^{12}$,

Że cudza bieda ludziom pośmiewiska

Bywa przyczyną (często się to dzieje:

Mówią, że wymysł ${ }^{13}$, gdy kto z żalu mdleje),

Przed Tobą samym, mego serca celu

I w gorzkich żalach słodki Zbawicielu,

Dolegliwości w życiu uznawane

Chcąca rozerwać ${ }^{14}$, myśli sturbowane

Wynurzam zawsze, pewną będąc tego,

Że pierwszy masz wzgląd na umartwionego.

Ty wiesz, mój Panie, jako od młodości

Wielem doznała w życiu przeciwności,

Jak w biednej wiek mój prowadziłam ${ }^{15}$ doli,

Nie mówiąc tego przed nikim, co boli.

Płacz mój był tylko świadkiem umartwienia,

Który trwać nie mógł nawet okamgnienia,

Bo w jednym punkcie ${ }^{16}$ wypogodzić czoło

Potrzeba było ${ }^{17}$ i patrzyć wesoło.

Nie chcę ja jednak wspominać tu tego,

Co się w młodości zdawa być ${ }^{18}$ przykrego,

Lecz $\mathrm{w}$ doskonalszym wieku ${ }^{19}$ utrapienia

Znoszone, Panie, z Twego dopuszczenia

Mężnym umysłem tu ${ }^{20}$ krótko wyjawię,

W melancholiji czas sobie gdy trawię.

Po zakończonym $z$ Twojego wyroku

Postanowieniu ${ }^{21}$ piętnastego roku

Wieku mojego lubo wyznać ${ }^{22}$ muszę, Żem miała męża ${ }^{23}$, któregom ${ }^{24}$ nad duszę

Więcej $^{25}$ kochała. Ale któż wypowie,

Jak mnie martwiło jego słabe zdrowie, Jego zemdlone w paroksyzmie siły?

Rkps B: Wiedzac obłudne światowe igrzyska.

Rkps J: wymst (błąd).

rozerwać - przerwać, zatrzymać.

Rkps J: prowadziła.

Rkps B: punkie (błąd); $w$ jednym punkcie - od razu, momentalnie.

Rkps B: byta.

Rkps B: być zdawa.

$w$ doskonalszym wieku - w latach dojrzalszych.

Rkps J: tę (błąd).

Rkps J: Postanowienia; Postanowieniu - małżeństwie, zamążpójściu.

Rkps B: zeznać.

Szyk przestawny: chociaż muszę wyznać, że po zawarciu z Twojego wyroku małżeństwa w piętnastym roku mego życia miałam męża.

Rkps B: którego.

Rkps B: Więcejm. 
Nie dla przyczyny jakiej ${ }^{26}$ lubieżności

Te przenikały serce moje mdłości,

Bo za szczęśliwa znam się być w tej mierze,

Że mnie do złego chęć nigdy nie bierze,

75 Ale imem go serdeczniej ${ }^{27}$ kochała,

Tym cięższy, patrząc, ból na sercu ${ }^{28}$ miała,

Obawiając się kożdego momentu

Nowej z choroby ${ }^{29}$ przyczyny lamentu.

W tym umartwieniu jeszczem te nadzieje

$80 \quad$ Miała, że kiedyż-tedyż ozdrowieje.

Po długim jednak czekaniu tej pory,

Widzac $^{30}$, że zawsze jednostajnie chory

Był, ani leki, ani doktorowie

Mogli salwować utracone zdrowie,

85 Tak zawszem w sercu umartwiona ${ }^{31}$ była

I bezprzestannie tymem się trapiła,

Żem często w mdłościach widziała mojego

Leosia, w życiu najukochańszego.

Nie dosyć jednak na tym jeszcze było,

90 Choć mnie to wszystko niezmiennie ${ }^{32}$ martwiło -

Więcej dopuszczasz utrapienia, Panie,

Nie majac względu na moje stroskanie,

W czym się wszechmocność daje widzieć Twoja,

Bo czego słabość nie zniosłaby moja,

95 Ty dopuszczając na mnie utrapienia,

Dodajesz siły do onych znoszenia.

Przyznać to sama $z$ doświadczenia muszę,

Że w ciele jakąs ${ }^{33}$ mam rogatą duszę ${ }^{34}$,

Kiedy podtenczas $z$ nim się nie rozstała,

100

Jakom wiadomość z Polski odebrała,

Że ojciec chory bez nadziei leży,

O czym posłaniec po posłańcu bieży,

Donosząc, do rąk list dając po liście,

W których to pisza ${ }^{35}$ do mnie oczywiście ${ }^{36}$,

Rkps B: swojej.

Rkps B: serdecznie.

Rkps B: na sercu ból.

Rkps B: Nowej choroby.

Rkps B: Wiedząc (błąd).

Rkps B: umartwiona.

Rkps B: nieznośnie.

Rkps J: jakoś.

rogata duszę - tj. duszę pełną samozaparcia, wytrzymałą; zwrot frazeologiczny notowany w Nowej księdze przysłów i wyrażeń przysłowiowych polskich (W oparciu o dzieło S. Adalberga oprac. Zespół Red. pod kier. J. Krzyża now skie go. T. 1. Warszawa 1969, s.v. dusza, s. 52).

Rkps B: piszac.

oczywiście - wyraźnie. 
105 Że sobie widzieć mnie przed śmiercią ${ }^{37}$ życzy

I od wysłania do mnie $z$ listem liczy

Dni, z umartwieniem czekając przybycia,

Żeby mnie jeszcze mógł widzieć za życia

I błogosławić ${ }^{38}$ córkę wraz z wnukami ${ }^{39}$,

110 Wszystkiemi tego pragnacy siłami.

Któż moję słabość pojmie i wypowie,

Która znieść ledwie mogło ${ }^{40}$ słabe zdrowie,

$Z$ tej swój poczatek mające ${ }^{41}$ przyczyny,

Żem odbierała ${ }^{42}$ tak smutne nowiny?

115 Trzeźwię się przecie i choć byłam chora,

Wybrać się każę w tę drogę niesporą ${ }^{43}$.

Zachodzą wozy na dziedziniec, żeby

Układać rzeczy, które do potrzeby

Zgodzić się mogły ${ }^{44} \mathrm{w}$ takowej podróży,

120 Ale wyjeżdżać czas jakoś nie służy.

Gdy ${ }^{45}$ się dni kilka ten wyjazd odwłoczy ${ }^{46}$,

Co mnie trapiło, ani od łez oczy

Osychać mogły, bo serce wzruszyło 47

To, co przede mną tajonego było,

125 Dowiaduję się, tak będąc stroskaną,

O tym, co nową rani serce rana,

Która, znać, że je mocno przenikała,

Kiedym od żalu razy kilka mdlała

I od pamięcim prawie odchodziła,

130 Wziąwszy wiadomość, żem ojca straciła ${ }^{48}$.

Co się w takowym razie ze mną działo,

Myślić się nawet, gdy piszę, nie chciało,

Ażeby w sercu nie odnowić ${ }^{49}$ rany

Tą myśla, że już ojciec tak kochany

135

Nie żyje. Ciebie jednak zawsze o to ${ }^{50}$

$Z$ pokorną serca upraszam prostota,

Rkps B: przed śmiercia mnie.

Rkps J: Błogosławić (błąd, lipometria).

z wnukami - w roku 1747 Anna i Leon Radziwiłłowie mieli dwoje dzieci: Teofilę (1745 - zm. po 1781) i Mikołaja (1746-1795).

Rkps B: mogło ledwo.

Rkps B: majacy.

Rkps B: odebrata.

niespora - męcząca, trudną, niełatwą.

do potrzeby / Zgodzić się mogły - mogły się okazać przydatne.

Rkps B: Gdyż.

Rkps B: przewłoczy; się ... odwłoczy - opóźni się, odwlecze.

Rkps J: uraziło (błąd, hipermetria).

Ojciec autorki, Maciej Mycielski, zmarł 3 X 1747 w wielkopolskim Szubinie. Córka przebywała wówczas najprawdopodobniej w Szydłowcu (podówczas północna Małopolska).

Rkps B: odmienić.

Rkps J: jednak o tą (błąd, lipometria). 
Żebyś go przyjać chciał do chwały Twojej -

Nie odrzucajże, Panie, prośby mojej!

Długom w tych żalach żyła ${ }^{51}$ umartwiona ${ }^{52}$,

W myślach stroskanych będąc roztargniona ${ }^{53}$

To śmiercią ojca, to chorobą męża

Trudząc się, która żal w sercu natęża

Przez wzgląd bojaźni, aby w swej słabości

$Z$ tego nie poszedł świata do wieczności.

145 Gdybym wiedziała, że się życzyć godzi,

Co w takim razie żal w umyśle ${ }^{54}$ rodzi,

Bez zwłoki umrzeć wolałabym sama,

Żeby śmierć była żalów moich tama.

Lecz że inaczej z Twej się woli dzieje,

Na sądów Twoich wspomnienie ${ }^{55}$ truchleje,

Kiedy po siedmiu latach zakończonych

I niedziel kilka $\mathrm{z}$ czasem upłynionych ${ }^{56}$

$\mathrm{W}$ przeznaczonym mi małżeństwie przeżytych ${ }^{57}$,

Z Twoich wyroków przed ludźmi ukrytych,

155 Odebrać Ci się, Panie, podobało

To, co szczególnie mnie kontentowało

W stroskanym życiu, bom stąd ulgę miała,

Gdym po słabości zdrowego widziała ${ }^{58}$.

Teraz zaś żadna ${ }^{59}$ pociech alternata ${ }^{60}$

Smutków i żalów moich nie przeplata,

Lecz nowe coraz utrapienia fale

Nieznośne ${ }^{61} \mathrm{w}$ sercu pomnażają żale,

Tak że osuszyć źrzenic rozkwilonych

Nie można w troskach nieuspokojonych.

165

Ledwie $^{62}$ co jeszcze $z$ łez nieoschłe oczy

Przecieram, nowy żal nowe łzy tłoczy ${ }^{63}$

I w tej mnie doli doświadczenie uczy,

Że jedna bieda nigdy nie dokuczy ${ }^{64}$.

Rkps J: Długo w tych żalach żyłam.

Rkps B: umartwiona.

Rkps B: roztargniona; roztargniona - rozerwana.

Rkps J: umuśle (błąd).

Rkps J: wspomnione (błąd).

Kiedy po siedmiu latach zakończonych / I niedziel kilka z czasem upłynionych - po upłynięciu siedmiu lat i kilku tygodni.

Rkps B: przebytych.

Mąż autorki zmarł w Nieświeżu 7 III 1751.

Rkps B: żadnych.

żadna pociech alternata - żadna radosna odmiana.

Rkps B: Nieszczęsne.

Rkps B: Ledwo.

Rkps B: Przeciram, nowy więcej łez tłoczy (błąd, lipometria).

jedna bieda ... nie dokuczy - zwrot przysłowiowy (zob. Nowa księga przysłów polskich i wyrażeń przysłowiowych, t. 1, s.v. bieda, s. 79). 
Miałam ich wprawdzie w życiu moim dosyć, Kiedy cenzury niewinne ${ }^{65}$ ponosić I świegotliwych języków ${ }^{66}$ obmowy Musiałam $^{67}$, skąd żal w sercu zawsze nowy Trapił mnie ciężko, ale mnie cieszyła Niewinność, która jawna Tobie ${ }^{68}$ była, Skąd potym mało dbałam na gadanie

Niesłuszne, bo tych trudne tamowanie (Zwłaszcza kto przywykł innych cenzurować ${ }^{69}$, Trudno takiego języka tamować). Ty, co serc ludzkich przenikasz skrytości ${ }^{70}$,

180 Wiesz o mym życiu i o niewinności, Wiesz innych moich umartwienia wiele ${ }^{71}$, Jako się nawet dawni przyjaciele $Z$ wielka odmiana teraz prezentują, Choć w umartwieniu niby mnie żałują, W którym dla mego ciężkiego stroskania Od nieprzyjaciół godnam zlitowania. Tak com pociechy z nich się spodziewała, Większa do żalu przyczyna ${ }^{72}$ się stała Jednakże ja chcę dobrym za złe płacićc ${ }^{73}$, Nie chcąc tej łaski Twojej dla nich tracić. Proszę Cię, daj im za tę ich odmianę Pomyślność, zdrowie niezalterowane ${ }^{74}$.

cenzury niewinne - niezawinione krytyki.

świegotliwych języków - plotkarzy, niewyparzonych gąb.

Rkps B: Cierpiałam.

Rkps B: Tobie jawna.

cenzurować - oceniać, krytykować.

Ty, co serc ludzkich przenikasz skrytości - nawiązanie do biblijnych określeń Boga jako tego, który potrafi przejrzeć ludzkie wnętrze. Por.: „badający się serc i nerek, Boże” (Ps 7, 10; wszystkie cytaty z Biblii za edycją: Biblia $w$ przekładzie księdza Jakuba Wujka z $1599 \mathrm{r}$. Transkrypcja typu „B” oryginalnego tekstu z XVI w. i wstępy ks. J. Frank ow ski. Wyd. 8. Warszawa 2013); „Ja, Pan, badający serca i doznawający nerek, który daje każdemu według drogi jego [...]” (Jr 17, 10). Fraza ta uskrzydliła się. Por.: „Boże! który okiem swem przenikasz skrytości, / Tobie się ja poruczam w mojej niewinności" (Pieśń o uwięzionym Samuelu Zborowskim. W: Pamiętniki do życia i sprawy Samuela i Krysztofa Zborowskich. Zebrał Ż. Pa uli. Lwów 1846, s. 96); „Boże, który okiem swym przenikasz skrytości / [...] wszak Ty wiesz o mojego serca niewinności” (H. M o r s zty n, Historyja barzo piękna o Talezie, królewicu lidyjskim, a o Perepodzie, królewnie aragońskiej. W: Filomachija. Wyd. R. G rześ k ow i a k. Warszawa 2000, w. 741, 748); „Tobie, który najgłębsze przenikasz skrytości” (Z. M o r s z t y n, Pieśń w ucisku. W: Muza domowa. Oprac., przedm. J. D ü r r - D u r ski. T. 1. Warszawa 1954, w. 123).

Wiesz innych moich umartwienia wiele - znasz wiele innych moich zmartwień.

Rkps B: przyna (błąd).

dobrym za złe płacić - zwrot utarty (zob. Nowa księga przysłów i wyrażeń przysłowiowych polskich, t. $3\langle 1972\rangle$, s.v. złe, s. 71), nawiązujący do słów św. Pawła: „Nie daj się zwyciężyć złemu, ale zwyciężaj złe w dobrym” (Rz 12, 21), dla których kontekstem jest nauczanie Chrystusa o potrzebie miłowania nieprzyjaciół (por. Mt 5, 43-45).

niezalterowane - nieodmienne, stałe. 
W jednych szczególnie opiekunach ${ }^{75}$, Panie,

Twoje nade mna czynisz zlitowanie,

195

Bo gdybym była w tym stanie inaczéj

Została, umrzeć trzeba by $z$ rozpaczy.

Lecz ci sa moją radą ${ }^{76}$ i obroną,

I w przeciwnościach wszelakich zasłona,

Skąd dla mnie w żalach pociecha niemała,

200 Żem się tak możnym ${ }^{77}$ w opiekę dostała,

Niechaj Cię za to wszystkie kreatury

Nad samych niebios wynoszą struktury,

Niech dobroć Twoja będzie wychwalona

W świecie od Anny, w niebie od Leona.

205 Nie chcę tu dla mnie respektów świadczonych

Wyliczać, przez wiek mój nieodsłużonych ${ }^{78}$,

Którem w najcięższym razie uznawała ${ }^{79}$

Od księcia - w życiu anioła ${ }^{80}$ - Michała

I od kochanej ciotki ${ }^{81}$, która matka

210 Stała się dla mnie $z$ kompasyją ${ }^{82}$ rzadką $^{83}$,

Ubolewając nade mna w słabości,

Jako jest pani pełna łaskawości -

Boże ${ }^{84}$, od Ciebie już sa policzone,

Za co im w niebie gotujesz koronę ${ }^{85}$.

215 Ja się do mojej biedy opisania

Powracam, którą z Twego dopuszczenia

Znoszę dla znacznej przyjaciół odmiany,

Choć w tym znam umysł wyperswadowany ${ }^{86}$,

Bo jak cenzury, tak ludzkiej odmiana ${ }^{87}$

220

Przyjaźni często jest praktykowana ${ }^{88}$.

Gdy Radziwiłłowa została wdową, zaopiekowali się nią krewni męża: hetman wielki litewski Michał Kazimierz Radziwiłł (1702-1762) i jego żona, Franciszka Urszula z Wiśniowieckich (17051753).

Rkps B: rada moja.

Rkps J: możnej.

przez wiek ... nieodsłużonych - niezasłużonych z racji młodego wieku.

$w$ najcięższym razie uznawała - doznawała w najcięższej sytuacji.

$w$ życiu anioła - wcielonego anioła.

od kochanej ciotki - Franciszka Urszula była córką Janusza Wiśniowieckiego, ojczyma Weroniki $z$ Konarzewskich, matki autorki.

Rkps B: kompasyi.

z kompasyja rzadka - z rzadko spotykanym współczuciem.

Rkps J: Bole.

$w$ niebie gotujesz koronę - w Nowym Testamencie kilkakrotnie wspomina się o koronach (wieńcach), którymi Bóg nagrodzi sprawiedliwych po śmierci (por. 2 Tm 4, 8; Jk 1, 12; 1 P 5, 4; Ap 2, 10). Symbolizują one życie wieczne w chwale niebiańskiej. $w$ tym znam umyst wyperswadowany - jestem $z$ tym pogodzona.

Rkps B: Bo tak cenzury, jako ludzkiej odmiana (błąd, hipermetria).

Rkps J: często niepraktykowana. 
Lecz żeś mi serca odebrał kompana

(Przez co jest nigdy niezgojona rana,

Bo przez takowe mnie osierocenie

Najnieznośniejsze cierpię utrapienie,

W którymże biedny wiek muszę prowadzić,

W swych ${ }^{89}$ troskach sobie nie umiejacc radzić),

Dla pozostałych kłopotów i trudów

Wzywam Twojego miłosierdzia cudów, Z łzami Cię żebrzac o tę łaskę ${ }^{90}$, Panie,

Żebyś mi w moim opłakanym stanie

Był protektorem, pomoca i rada,

Bo w Tobie ufność swą sieroty kładą.

Pewna $^{91}$ nadzieją ${ }^{92}$ proszących Cię, Boże,

Wiem, że być liższe ${ }^{93}$ stworzenie nie może

235 Nade mnie, która dla grzechowych złości ${ }^{94}$

I wielu ${ }^{95}$ innych moich nieprawości

Niegodną się być Twego zlitowania

Wyznawam, przecie płacz mój i wzdychania

Obracam $\mathrm{z}$ pewną do Ciebie ufnością,

240 Wiedzacc ${ }^{96}$, jakoś ${ }^{97}$ nas ukochał miłością ${ }^{98}$.

Twoje to słowa sa prawda przedwieczną ${ }^{99}$,

Grzeszników wszystkich ucieczką ${ }^{100}$ bezpieczną ${ }^{101}$,

Żeś przyszedł szukać nie sprawiedliwego,

Ale przestępców przykazania Twego ${ }^{102}$,

245 Iżeś za grzesznych swą krew wylał ludzi,

To we mnie pewność żywej wiary budzi ${ }^{103}$,

Że choć niegodnej, wysłuchasz grzesznicy,

Twoich instynktów ${ }^{104}$ i łask przeciwnicy.

Rkps J: Wszych.

Rkps J: o te łaski.

Pewna - upewniona.

Rkps B: nadzieja.

liższe - lichsze.

Rkps J: grzechów i złości; dla grzechowych złości - z powodu grzesznych występków.

Rkps B: wiela.

Rkps B: Widzac.

Rkps J: jaka.

ukochał miłościa - zwrot o proweniencji biblijnej, por.: „A miłością wieczną umiłowałem cię [...]” (Jr 31, 3).

Rkps J: prawdo przedwieczna; prawda przedwieczna - nawiązanie do obiegowej metonimii Boga: „prawdo przedwieczna” (łac. aeterna Veritas).

Grzeszników ... ucieczka - tytuł „Ucieczki grzeszników” (łac. Refugium peccatorum) zwykle odnoszony był do Maryi. Por. jednak: „I zstał się Pan ucieczką ubogiemu” (Ps 9, 10).

Rkps J: ucieczko bezpieczna.

Por. słowa Chrystusa: „Abowiem nie przyszedłem wzywać sprawiedliwych, ale grzesznych” (Mk 2, 17).

Rkps B: żywej wiab (brak końca wersu).

instynktów - zachęt, pobudek. 
Proszę Cię najprzód, w mych żalach strapiona,

Żebyś do chwały swej przyją Leona

I między świętych pomieścić go raczył,

Bo ufam, żeś go do nieba przeznaczył.

Jego cierpliwość, jego utrapienia

Są mi nadzieją tego przeznaczenia,

255

Ponieważ w życiu szedł drogą krzyżową,

Bólów przyczynę zawsze mając nową ${ }^{105}$.

Jeżeli jednak $\mathrm{z}$ swojej ułomności

Nie wypłacił się Twej sprawiedliwości,

Ja resztę kary przyjmuję ${ }^{106}$ na siebie,

260 Tylko $z$ świętemi daj mu miejsce w niebie.

Masz i mnie wprawdzie za co karać ${ }^{107}$, Panie,

Za wielorakie moje ${ }^{108}$ wykraczanie

Przeciwko Twoich praw świętych ustawie,

Lecz że się $z$ tymi ${ }^{109}$ obchodzisz łaskawie,

265 Co $z$ heroicznej bliźniego miłości

Rad[zi sa] $]^{110}$ wszystkie cierpieć przeciwności,

Więc ufam, że mi wszystkie moje winy

Odpuścisz z Twojej dobroci jedynéj.

Kiedy $\mathrm{Z}$ afektu poprzysiężonego ${ }^{111}$

270 Ochotnie sama dopraszam się tego,

Żebyś dopuszczał na mnie utrapienia

Dla duszy jego z czyśca wybawienia,

Niech będzie moja słabość i choroba

Pierwsza Twojego dopuszczenia proba ${ }^{112}$,

275 W której ile znieść może słaba ${ }^{113}$ siła,

Największe męki rada bym znosiła.

Ale się, widzę, wszystkie spólnie biedy

Skupiły razem, bom jeżeli kiedy

Większe znać mogła w życiu przeciwności,

280

Jako gdy w ciężkiej zostając słabości

Bez polepszenia zdrowia, coraz więcéj

Znajac się słabą od kilku miesięcy

I niżli życia śmierci bliższa prawie

Sądząc się często, tą myślą się bawię ${ }^{114}$,

Rkps J: zawsze mu nienowa.

Rkps B: przejmuję.

Rkps J: karać za co.

Rkps J: może (błąd).

Rkps B: $z$ złemi (błą).

Poprawka wydawcy. Rkps B i rkps J: Rada bym.

$z$ afektu poprzysiężonego - $\mathrm{z}$ powodu ślubu miłości, tj. przysięgi małżeńskiej.

Pierwsza Twojego dopuszczenia proba - pierwszym doświadczeniem z tych, jakie dopuścisz, ześlesz.

Rkps J: słaba może.

się bawię - zaprzątam się. 
Interesami trudzac się $e^{115}$ ustawnie $^{116}$,

Co życia końcem będzie, widzę jawnie.

Te jednak biedy ${ }^{117}$, ile słaba siła

Zdoła, cierpliwie będę ponosiła,

Tylko Cię proszę, przy moich kłopotach

290 Na pozostałych nie karz mię sierotach ${ }^{118}$,

Które pamiątką mojego małżeństwa

I znakiem Twego są błogosławieństwa.

Bo jak nieznośną czułam w sercu trwogę,

Wyrazić tego zupełnie nie mogę,

295 Kiedym widziała najstarszego syna,

W którym mych pociech nadzieja jedyna,

Niedziel czternaście tak ciężko chorego,

Żem razy kilka za konającego

Już miała, na co patrząc, ledwiem żyła,

300

Takem się tego słabością trapiła,

Obawiając się co moment przyczyny

Śmierci dla siebie z śmierci tej dzieciny.

Myśliłam, w żalu tym nieutulona,

Że być od Ciebie muszę opuszczona,

305 Kiedy mi, Panie, odbierasz to dziécię,

Które nad własne więcej kocham życie.

Alem się prędko rekoligowała ${ }^{119}$

I samam siebie o to strofowała,

Żem się na Twoję dobroć nie spuściła,

310 Której, niegodna, jużem doświadczyła,

Gdyś mnie w podobnym zasmuconą razie

Cieszył w słynącym cudami obrazie

Na miejscu, które Jezusową Wolą

Zowią ${ }^{120}$, żałosną ${ }^{121}$ zamieniając dolą

315

W radość obfita, gdziem jak przyjechała

I do kościoła wnieścem rozkazała

Toż samo dziecię ledwie żywe prawie,

Wraz żeś mu zdrowie przywrócił łaskawie.

Interesami trudzac się - mowa zapewne o roszczeniach, $\mathrm{z}$ jakimi po śmierci męża Radziwiłłowej wystapił wojewoda brzesko-kujawski Antoni Dąmbski, żądając oddania obciążonych długiem dóbr szydłowieckich (wdowa ostatecznie spłaciła wierzyciela).

117 Rkps B: kiedy (błąd).

Na pozostatych nie karz mie sierotach - nie karz mnie śmiercią osieroconych dzieci. Prócz już wspomnianych - Teofili i Mikołaja, Radziwiłłowie mieli jeszcze dwóch synów: zmarłego w dzieciństwie Michała (ur. 1748) oraz Macieja (1749-1800). się ... rekoligowała - opamiętała się.

Mowa o sanktuarium w Paradyżu (obecne województwo łódzkie), zwanym też Wielką bądź Jezusową Wolą, w którym znajduje się słynący cudami obraz Chrystusa Cierniem Koronowanego. Miejscowość położona jest kilkadziesiąt kilometrów od Szydłowca. 
Tego mnie cudu ${ }^{122}$ cieszyło wspomnienie I sprawowało żalów utulenie, Czyniąc mi ufność i dobrą nadzieję, Że z Twojej łaski znowu ozdrowieje. Jakoż się według tej ufności stało, Bo dziecię cudem Twoim ozdrowiało, Skąd bojaźń, która mocno mnie smuciła, W pociechę Twoja dobroć zamieniła.

Za co, żebym Cię godnie mogła chwalić, Ty serce moje ogniem racz zapalić Twojej miłości, żebym Ci czyniła

330 Dzięki powinne, dokąd będę żyła, Wezwawszy wszystkie do wielbienia Ciebie Stworzenia, co sa na ziemi i w niebie ${ }^{123}$. Już teraz wszystkie kłopoty i troski

Z Twej dopuszczone na mnie ręki boskiéj ${ }^{124}$

Chętnie przyjmować i cierpliwie znosić Pragnę, tylko Cię nie przestawam prosić, Żebyś dał łaskę i siłę do tego,

Co mi dopuszczasz cierpieć przeciwnego ${ }^{125}$. Tylko niech mi się jednę ekscypować ${ }^{126}$

340 Godzi, pozwól mi, proszę, kontraktować ${ }^{127}$, Która nieznośną w sercu czyni trwogę, Tak że żyć ledwie $z$ turbacyi ${ }^{128}$ moge, Bo gdy widziałam najstarszego syna, W którym mych pociech nadzieja jedyna ${ }^{129}$,

345 Już bez nadzieje życia będącego, Tak przez chorobę zmizerowanego, Boję się jednak i mocno się trwożę, Myśląc, że jeszcze zachorować może. Ale że w Twojej władzy śmierć i życie, Więc pozwól, proszę, niech żyje to dziécię, Które z przykazań Twoich drogi zboczyć Nie mogło jeszcze ani w czym wykroczyć, Przez co by śmiercią miało być karane. A tak bojaźni zgoisz w sercu ranę

355 Żałosnej matki, która wszystkie troski Z Twojej dopuszczone na nię ręki boskiéj

Rkps B: cudo (błąd).

Rkps B: i niebie.

Poprawka wydawcy. Rkps J: Z Twojej dopuszczone na mnie ręki boskiéj (hipermetria). przeciwnego - niepomyślnego.

jednę ekscypować - uczynić wyjątek w jednej sprawie.

kontraktować - zawrzeć umowę.

$z$ turbacyi-ze zmartwienia.

w. 343-344, por. w. 295-296. 
Chętnie przyjmować i cierpliwie znosić

Pragnie, tylko Cię nie przestawa prosić,

Żebyś dał łaskę i siłę do tego,

Co mi dopuszczasz cierpieć przeciwnego ${ }^{130}$.

To moje do Twej woli stosowanie

W otwarte rany ofiaruję, Panie,

O to pokornie śmiem Cię suplikować,

Żebyś mnie raczył w nich spólnie zachować

365

$Z$ dziećmi mojemi. Ja, choć przeniewierca ${ }^{131}$,

Do Twojego się sama cisnę serca,

Żebyś oziębła gorącym kochaniem

Zapalił, proszęć z łez gorzkich wylaniem.

A Teofilę w prawej ręki [r]anie ${ }^{132}$

370 Składam, mój Jezus, jedyne kochanie ${ }^{133}$,

Mikołaja zaś w lewej [r]anie ${ }^{134}$ ręki,

Żebyś znoszone jego bóle, męki

Przyjąwszy, dać mu raczył dobre zdrowie,

A ten przed światem dobroć Twa opowie,

Michała składam w prawej [r]anie ${ }^{135}$ nogi,

Chciej go ratować ${ }^{136}$, Zbawicielu drogi,

Macieja przyjmij w lewej nogi ranę -

Tak wszystkie dzieci w rany Twe oddane

I z matką razem chciej przyjąc łaskawie,

Na tym dni, prosząc Cię, niech trawię,

Biedna sierota i stroskana wdowa,

Anna z Mycielskich, ksna ${ }^{137}$ Radziwiłłowa.

w. 355-360, por. w. 333-338. Występujące w tekście repetycje świadczyć mogą o tym, że utwór nie został jeszcze wykończony, gdyż trudno wskazać uzasadnienie artystyczne dla takich powtórek.

choć przeniewierca - choć zawiodłam zaufanie.

Poprawka wydawcy (por. w. 377). Rkps J: Panie (błą).

Ten i następne zwroty dotyczące składania dzieci w ranach Chrystusa są charakterystyczne dla ówczesnej literatury dewocyjnej. Por. np.: „Przyjmij mię, mój drogi Jezu, do otwartej rany lewej nogi. Tam dziś grzeszną duszę moję i twarde do pokuty serce składam i zanurzam” (Codzienne akty $z$ nabożeństwem do ran $w$ nogach Zbawiciela ukrzyżowanego. Poznań $\left.1700, k . \mathrm{A}_{2} \mathrm{v}\right) ;$,W te przenajdroższe rany ofiaruję $\mathrm{Ci}$, o najłaskawszy Jezu, wszystkie moje pragnienia pobożne i afekty nabożne, abyś ich tymi oczyścił źrzódłami i mile przyjął" (Głos synogarlicy na pustyni świata tego jęczacej, to jest Nabożne duszy chrześcijańskiej rozmyślania [...]. Lwów 1741, s. 481).

Poprawka wydawcy (por. w. 377). Rkps J: Panie (błąd).

Poprawka wydawcy (por. w. 377). Rkps J: Panie (błąd).

Poprawka wydawcy. Rkps J: poratować (błąd, hipermetria).

$k s n a$ - tak transkrybowano skrót $X^{\text {na }}$, którego rozwinięcie do pełnej formy ks[ięż]na naruszałoby rytm 11-zgłoskowca. 


\section{Abstract \\ ROMAN KRZYWY University of Warsaw \\ DEFIANT SOUL AN AUTOBIOGRAPHICAL POEM BY ANNA LUDWIKA RADZIWIŁLOWA DE DOMO MYCIELSKA}

The article contains an edition of an autobiographical poem by Anna Ludwika Radziwiłłowa de domo Mycielska (1729-1771) preceded by a literary historical introduction. The piece, unpublished so far, was restored as based on two handwritten copies. Anna Ludwika Mycielska married in 1744 Leon Michał Radziwiłł, with which she became close to the court of Franciszka Urszula Radziwiłłowa, a poetess and an animator of theatre life in Nesvish Castle. It is likely that Anna Ludwika started composing poems under Franciszka Urszula's influence. Sickly Leon Michał passes away in the year 1751. After his death the young widow, uncertain about her destiny and concerned about her children's sicknesses, composed a lamentatory verse in which she complains about the suffering after the death of her father and husband, the latter's long sickness and adequately unexplained defamation. Discouraged to people, she directs her complaint to God, combining an autobiographical statement with the phraseology typical of prayer literature. Anna Ludwika Radziwiłłowa's poem is an example of an $18^{\text {th }}$ century Polish female poetry which deserves extraction from manuscripts and description. 